Case report

\title{
Six cases of Solobacterium moorei isolated alone or in mixed culture in Hungary and comparison with previously published cases
}

\author{
Károly Péter Sárvári ${ }^{\mathrm{a},{ }^{*}}$, Dóra Sántha ${ }^{\mathrm{b}}$, Réka Kovács ${ }^{\mathrm{c}}$, Sándor Körmöndi ${ }^{\mathrm{d}}$, Zoltán Pető ${ }^{\mathrm{e}}$, \\ Tamás Vereb ${ }^{\mathrm{f}}$, Balázs Sztanó ${ }^{\mathrm{g}}$ \\ a Institute of Clinical Microbiology, University of Szeged, Szeged, Hungary \\ ${ }^{\mathrm{b}}$ Department of Oncotherapy, University of Szeged, Szeged, Hungary \\ ${ }^{c}$ Department of Dermatology and Allergology, University of Szeged, Szeged, Hungary \\ ${ }^{\mathrm{d}}$ Department of Traumatology, University of Szeged, Szeged, Hungary \\ e Department of Emergency Medicine, University of Szeged, Szeged, Hungary \\ ${ }^{\mathrm{f}}$ Department of Oral and Maxillofacial Surgery, University of Szeged, Szeged, Hungary \\ ${ }^{g}$ Department of Oto-Rhino-Laryngology and Head-Neck Surgery, University of Szeged, Szeged, Hungary
}

\section{A R T I C L E I N F O}

\section{Article history:}

Received 10 May 2020

Accepted 13 July 2020

Available online 7 August 2020

Handling Editor: Hanna Pituch

\section{Keywords:}

Solobacterium moorei

MALDI-TOF MS

Case report

\begin{abstract}
A B S T R A C T
Solobacterium moorei is a strict anaerobic gram-positive rod. It is found in the human microbiota in different parts of the body, but it also appears to be an opportunistic pathogen in some infectious processes. We describe six cases of severe infections identified in 2016 in which S. moorei was isolated alone or in mixed culture involving other anaerobes or both aerobic and anaerobic bacteria. Three cases were associated with the oral cavity, including a middle ear infection, a wound infection after total laryngectomy, and a mandibular abscess as a result of bisphosphonate therapy. In the other three patients, the sites of infection had no connections with the oral cavity and included chronic osteomyelitis of the tibia, a superinfection of cutaneous tuberculosis associated with hidradenitis suppurativa, and the isolation of $S$. moorei from the blood culture of a cachectic man with several comorbidities. Based on our findings, S. moorei does not appear to be that virulent of a bacterium; except for the case with bacteraemia, S. moorei was recovered as a co-pathogen in patients with several immunosuppressive predisposing factors. We highlight the finding that the routine use of MALDI-TOF MS in microbiology laboratories can in a timely and detailed manner identify members of mixed infections involving different anaerobic bacteria that may be rare and difficult-to-culture and identify species, such as S. moorei.
\end{abstract}

(c) 2020 Elsevier Ltd. All rights reserved.

\section{Introduction}

Solobacterium moorei is an infrequently isolated strict anaerobic gram-positive rod that is approximately $0.2 \times 0.4-0.7 \mu \mathrm{m}$ in size. It typically appears as a straight or slightly curved rod in pairs or in short chains without any flagella. It is relatively inactive biochemically, which makes it difficult to identify by classical methods. S. moorei was first described by Kageyama and Benno in 2000 [1], when it was isolated from human faeces and was considered a member of the intestinal microbiome. This Eubacterium-like bacillus was originally known as Bulleida extructa or Bulleida moorei. It

\footnotetext{
* Corresponding author. Institute of Clinical Microbiology, University of Szeged, Semmelweis Str. 6, H-6725, Szeged, Hungary.

E-mail address: sarvari.karoly.peter@med.u-szeged.hu (K.P. Sárvári).
}

differed from other gram-positive anaerobic genera such as Bifidobacterium, Lactobacillus, and Propionibacterium, and according to 16S rRNA gene sequencing, it had only $86 \%$ sequence homology with Erysipelothrix rhusiopathiae and $87 \%$ with Holdemania filiformis. Thus, this species was classified as a member of the new genus Solobacterium [1]. Although S. moorei was first isolated from human faeces, this bacterium is a constant member of the microbiota of the human oropharynx [2]. The involvement of S. moorei as an opportunistic pathogen in different infections has been reported in recent years. It is associated with different types of serious underlining diseases or predisposing factors, such as cancers, immunosuppressive status, intravenous drug abuse, septic pulmonary embolism, and thrombosis [3-5]. S. moorei has also been reported as a possible pathogen in oral infections, such as periimplantitis, periradicular lesions, or other endodontic infections 
[6-11]. Haraszthy et al. reported on the possible association of S. moorei with halitosis as a causative agent [2]. In most reported cases, S. moorei was isolated from mixed infections: three to eleven different aerobic and anaerobic species have been cultured in combination with $S$. moorei $[4,5]$. Few publications have described $S$. moorei as a causative agent of bacteraemia when isolated as a single pathogen or together with one or two other species [12,13].

Here we report six cases from 2016 in which S. moorei was isolated alone or together with different aerobic and anaerobic species from patients treated in various departments of the University Clinic, Szeged, Hungary. This study was approved by the Ethics Committee of the University of Szeged, according to the Declaration of Helsinki (1975) and its revision in 2002.

\section{Materials and methods}

Samples from the patients were transferred to the laboratory in anaerobic transport vials, except for the septic patient, from whom two sets of blood culture bottles (aerobic and anaerobic) were submitted. The samples were processed by standard methods [14] using anaerobic Schaedler blood agar (bioMérieux, Marcy l'Etoile, France) for the isolation of anaerobes by incubating the plates at $37^{\circ} \mathrm{C}$ for $48-72 \mathrm{~h}$ in an anaerobic chamber (Perkin Elmer, Beaconsfield, UK) $\left(85 \% \mathrm{~N}_{2}, 10 \% \mathrm{CO}_{2}, 5 \% \mathrm{H}_{2}\right)$. Simultaneously, the aerobic bacteria were cultured on Columbia (with $5 \%$ sheep's blood), chocolate, and eosin methylene blue agar plates (bioMérieux, France), and the fungi were cultured on Sabouraud agar plates (bioMérieux, France) at $35^{\circ} \mathrm{C}$ for $24 \mathrm{~h}$. The identification was performed with Matrix-Assisted Laser Desorption/Ionisation Time-ofFlight Mass Spectrometry (MALDI-TOF MS, Bruker Daltonik, Germany) using Biotyper Version 3.0 software. When the log (score) value of the strains was $\geq 2.000$, we accepted it as a reliable specieslevel identification result for all strains isolated from these patients. All $S$. moorei strains were identified with a $\log$ (score) value of $>2.000$ (between 2.04 and 2.288). The antibiotic susceptibility of the aerobic bacteria was determined by the disc diffusion method according to the EUCAST guidelines (http://www.eucast.org). Antibiotic susceptibility to penicillin, amoxicillin/clavulanic acid, clindamycin, imipenem, and metronidazole was assessed using the E-test (bioMérieux, France) on the $S$. moorei isolates obtained from the blood culture. For mixed infections involving anaerobic bacteria, including $S$. moorei, antibiotic therapy was determined according to known literature data [14,15].

\section{Case reports}

\subsection{Case 1}

A 58-year-old cachectic man with a previous medical record of alcoholic polyneuropathy, encephalopathy, chronic obstructive pulmonary disease, a broken left femoral neck, atherosclerosis, and neuromuscular dysfunction of the urinary bladder was admitted to the emergency department with dehydration, unproductive cough, and pain in the left kidney area. Chest CT diagnosed a right central lung carcinoma $(38 \times 48 \times 72 \mathrm{~mm})$ with hilar lymph node metastases, and a histopathological examination identified it as an anaplastic solid carcinoma. As sepsis developed (white blood cells: $29.40 \mathrm{G} / \mathrm{l}$, C-reactive protein: $361.2 \mathrm{mg} / \mathrm{dl}$, body temperature: $36.0^{\circ} \mathrm{C}$, blood pressure: $80-101 / 41-62 \mathrm{mmHg}$, pulse: $92-98$ beats/ $\mathrm{min})$, blood cultures were taken. A pure culture of $S$. moorei was isolated from one anaerobic bottle after $63 \mathrm{~h}$ of incubation. Antibiotic susceptibility testing was performed, and the minimum inhibitory concentration (MIC) values were as follows: penicillin, $0.016 \mu \mathrm{l} / \mathrm{ml}$; amoxicillin/clavulanic acid, $0.016 \mu \mathrm{l} / \mathrm{ml}$; clindamycin, $0.016 \mu \mathrm{l} / \mathrm{ml}$; imipenem, $0.002 \mu \mathrm{l} / \mathrm{ml}$; metronidazole, $0.064 \mu \mathrm{l} / \mathrm{ml}$.
The patient's clinical status deteriorated, he refused any type of therapy (including antibiotics), and he was transported to the Department of Internal Medicine. After $18 \mathrm{~h}$ of observation, he died of sepsis, accompanied by bronchiolitis, pulmonary oedema, and abscess followed by pyothorax in the upper lobe of the right lung (Table 1).

\subsection{Case 2}

Case 2 was a 71-year-old female patient with colorectal and facial skin cancers in her past medical history who had broken her right tibia twice, which had been treated with conservative therapy. Although her wound from the previously broken tibia had secreted serous fluid since 2010, she did not accept conventional health care; instead, she used alternative medical treatment over the following years. In 2016, her right leg was broken again, and she was admitted to the Department of Traumatology, where the injured tibia was plastered. Chronic osteomyelitis and a finger-sized fistula in the middle third of the tibia were diagnosed. Serous fluid from the fistula was sent to the microbiological laboratory for culturing, and large numbers of colonies of S. moorei, Actinomyces odontolyticus, Actinomyces turicensis, Veillonella atypical, and Atopobium rimae were isolated anaerobically. During the aerobic cultivation, a few colonies of Staphylococcus aureus and Klebsiella oxytoca were also isolated. The patient refused both operation for her right tibia and antibiotic drug administration. After local disinfection with povidone-iodine, she was dismissed from the Department of Traumatology. The outcome of this infection is unknown (Table 1).

\subsection{Case 3}

A 49-year-old man with a previous medical record of diabetes mellitus and hypertonia has been suffering from chronic hidradenitis suppurativa in the axillary, inguinal, and gluteal regions since 2004. In 2008, on the posterior part of the limbs, painful verrucous knots appeared, which were treated with antibiotics, but he did not recover. After two years, a punch biopsy from the arms identified tuberculosis verrucosa cutis, and his Mycobacterium tuberculosis complex PCR was positive. He received long-term antituberculotic therapy (isoniazid + pyrazinamide + ethambutol + rifampicin) until 2016, when his clinical status improved and the discharge disappeared. The crusted skin of the gluteal region was operated on many times. After recovery from the operations, signs of hidradenitis suppurativa appeared on the left gluteal region. A pus sample was taken and sent to the microbiological laboratory. S. moorei, Anaerococcus vaginalis, Prevotella timonensis, Prevotella nigrescens, Porphyromonas somerae, Anaerococcus hydrogenalis, and Streptococcus constellatus were isolated. All these bacteria were present with high colony counts in the sample. Due to this mixed infection, the patient received clindamycin per os $(2 \times 300 \mathrm{mg}$ per day $)$ therapy for one month. The patient recovered and has been controlled regularly through the present day (Table 1 ).

\subsection{Case 4}

In September 2015, a 53-year-old man with a previous medical history of chronic parodontopathy, hypertension, smoking, alcohol abuse, and cachexia was admitted to the Department of Oral and Maxillofacial Surgery. He suffered from mild swelling of the right cheek and experienced pain caused by the pressure. He had lost $15 \mathrm{~kg}$ of weight over the previous two months. A right maxillary sinus wall destructing cancer was found on a chest and neck CT, and histopathological examination identified invasive basaloid squamous cell carcinoma, stage III (T4NOM0). Two months later, a right hemi-maxillectomy with cervical block dissection was performed. 
Table 1

Microbiological results of the six cases where Solobacterium moorei was present alone or in mixed culture in the patient's sample.

\begin{tabular}{|c|c|c|c|c|c|c|c|}
\hline Cases & & Case 1 & Case 2 & Case 3 & Case 4 & Case 5 & Case 6 \\
\hline Sample type & & Blood culture & $\begin{array}{l}\text { Serous fluid from } \\
\text { tibia }\end{array}$ & $\begin{array}{l}\text { Pus from gluteal } \\
\text { region }\end{array}$ & Pus from mandibula & Pus from middle ear & $\begin{array}{l}\text { Wound of } \\
\text { laryngectomy }\end{array}$ \\
\hline \multirow[t]{8}{*}{$\begin{array}{l}\text { Isolated } \\
\text { species }\end{array}$} & \multirow[t]{6}{*}{ Anaerobic } & \multirow[t]{6}{*}{$\begin{array}{l}\text { Solobacterium } \\
\text { moorei }\end{array}$} & Solobacterium moorei & Solobacterium moorei & Solobacterium moorei & $\begin{array}{l}\text { Solobacterium } \\
\text { moorei }\end{array}$ & $\begin{array}{l}\text { Solobacterium } \\
\text { moorei }\end{array}$ \\
\hline & & & $\begin{array}{l}\text { Actinomyces } \\
\text { odontolyticus }\end{array}$ & $\begin{array}{l}\text { Anaerococcus } \\
\text { hydrogenalis }\end{array}$ & Fusobacterium necrophorum & $\begin{array}{l}\text { Actinomyces } \\
\text { randingae }\end{array}$ & Lactobacillus orale \\
\hline & & & $\begin{array}{l}\text { Actinomyces } \\
\text { turicensis }\end{array}$ & $\begin{array}{l}\text { Anaerococcus } \\
\text { vaginalis }\end{array}$ & & & $\begin{array}{l}\text { Fusobacterium } \\
\text { nucleatum }\end{array}$ \\
\hline & & & Atopobium rimae & Prevotella nigrescens & & & Prevotella buccae \\
\hline & & & \multirow[t]{2}{*}{ Veillonella atypica } & Prevotella timonensis & & & $\begin{array}{l}\text { Prevotella } \\
\text { nanceiensis }\end{array}$ \\
\hline & & & & $\begin{array}{l}\text { Porphyromonas } \\
\text { somerae }\end{array}$ & & & \\
\hline & \multirow[t]{2}{*}{ Aerobic } & & Klebsiella oxytoca & $\begin{array}{l}\text { Streptococcus } \\
\text { constellatus }\end{array}$ & & $\begin{array}{l}\text { Pseudomonas } \\
\text { aeruginosa }\end{array}$ & \\
\hline & & & $\begin{array}{l}\text { Staphylococcus } \\
\text { aureus }\end{array}$ & & & $\begin{array}{l}\text { Staphylococcus } \\
\text { aureus }\end{array}$ & \\
\hline Therapy & & $\begin{array}{l}\text { No antibiotic } \\
\text { therapy }\end{array}$ & No antibiotic therapy & Clindamycin & $\begin{array}{l}\text { Metronidazole, Amoxicillin/ } \\
\text { clavulanic acid }\end{array}$ & Ciprofloxacin & Metronidazole \\
\hline Clinical outc & ome & Died & No further data & Recovered & Recovered & Recovered & Recovered \\
\hline
\end{tabular}

In the Department of Oncotherapy, the patient received combined weekly scheduled chemotherapy $\left(30 \mathrm{mg} / \mathrm{m}^{2}\right.$ cisplatin intravenously) and radiotherapy $(2.8 \times 1.8 \mathrm{~Gy}+12 \times 1.8 \mathrm{~Gy})$. In February 2016 , he complained of double vision, radiating pain in the right ear, and hearing loss. Purulent inflammation of the right middle ear was diagnosed. Puncture was performed, and from the gained pus, S. moorei and Actinomyces randingae were isolated from the enrichment broth. S. aureus and Pseudomonas aeruginosa were isolated in large numbers of colonies after $24 \mathrm{~h}$ of aerobic incubation. Because both aerobic strains were fully susceptible to ciprofloxacin, the patient received i.v. ciprofloxacin therapy $(2 \times 400 \mathrm{mg}$ daily) for five days. He did not receive any anti-anaerobic drugs because $S$. moorei and $A$. randingae were considered contaminants, and the patient finally recovered (Table 1 ).

\subsection{Case 5}

A 63-year-old man had been suffering from mitral insufficiency, ischaemic heart disease, and recurrent metastatic urinary bladder cancer since 2008. He received palliative chemotherapy (Tegafur) for bone metastasis between September and November 2005 (which was stopped due to gastric complaints), and bisphosphonate (sodium clodronate) therapy was administered between 2008 and 2011. Presumably due to the side effects of the bisphosphonate therapy, the patient lost all his teeth. In 2011, due to osteonecrosis, his mandible had to be resected marginally, and a sequestrectomy was performed. In 2016, he was admitted to the Department of Oral and Maxillofacial Surgery with a submandibular abscess because of suspected medication-related osteonecrosis of the jaw as a result of the bisphosphonate therapy. The panoramic X-ray showed osteopenia between the lower premolar regions. The CT scan revealed a definitive abscess in the left mandibular region and also raised the suspicion of chronic osteomyelitis. The abscess ruptured spontaneously, and pus was sent in anaerobic transport media to the microbiological laboratory. S. moorei and Fusobacterium necrophorum were isolated with high colony counts. The patient received i.v. amoxicillin/clavulanic acid $(3 \times 1.2 \mathrm{~g}$ daily for five days $)$ and metronidazole $(2 \times 500 \mathrm{mg}$ daily for five days). Irrigation with povidone-iodine and hydrogen peroxide was recommended when he was discharged. After a five-day-long stay at the Department of Oral and Maxillofacial Surgery, he was transferred to the Department of Oncotherapy, and amoxicillin/clavulanic acid was administered for seven more days per os. He recovered from the infection (Table 1).

\subsection{Case 6}

A 43-year-old man with a previous medical history of heavy smoking and alcohol abuse was admitted to the Department of OtoRhino-Laryngology and Head-Neck Surgery with stage II laryngeal squamous cell carcinoma. Despite undergoing radiotherapy, hemilaryngectomy, urgent tracheostomy, and finally, total laryngectomy were performed because of the cancer progression. A sample from the surgical wound during the total laryngectomy was sent to the microbiological laboratory, and S. moorei, Fusobacterium nucleatum, Prevotella nanceiensis, Lactobacillus orale, and Prevotella buccae were isolated in large numbers under anaerobic conditions. The patient received i.v. metronidazole $(2 \times 500 \mathrm{mg}$ daily) therapy for seven days. No further infectious process was observed in this patient after the laryngectomy (Table 1 ).

\section{Discussion}

After the introduction of MALDI-TOF MS for the routine

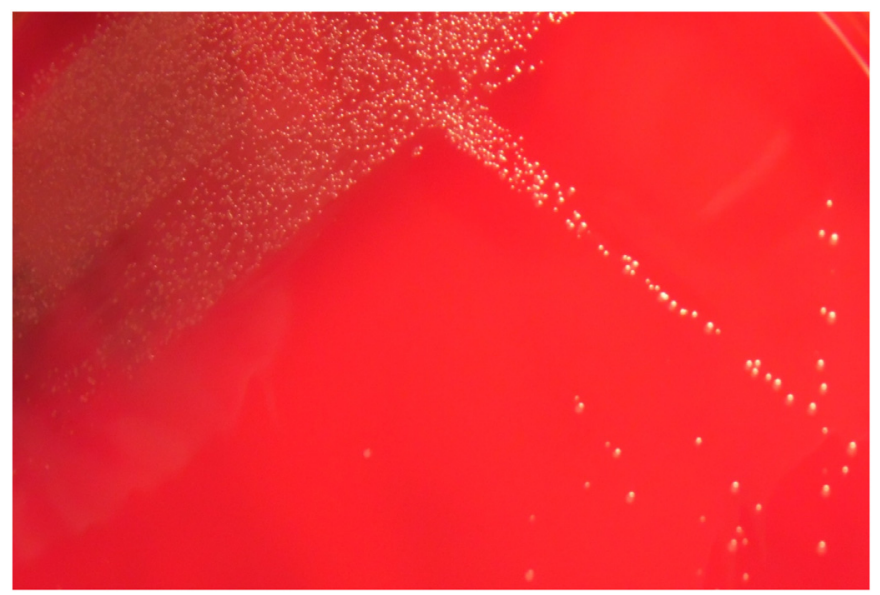

Fig. 1. S. moorei colonies of the subculture on Schaedler anaerobic blood agar after 48 hours of incubation in anaerobic chamber 
Table 2

Overview of earlier published case reports of infections when S. moorei was isolated.

\begin{tabular}{|c|c|c|c|c|c|c|}
\hline Ref. & Sample type & Patient & Medical history & Culture results & Antimicrobial therapy & $\begin{array}{l}\text { Clinical } \\
\text { outcome }\end{array}$ \\
\hline [13] & Blood culture & $\begin{array}{l}\text { 43-year-old } \\
\text { woman }\end{array}$ & Cervix carcinoma & Solobacterium moorei & Cefuroxime $\rightarrow$ Piperacillin/tazobactam & Recovered \\
\hline [3] & Blood culture & $\begin{array}{l}\text { 67-year -old } \\
\text { man }\end{array}$ & Multiple myeloma & Solobacterium moorei & Cefepime Amikacin Vancomycin & Recovered \\
\hline [12] & Blood culture & $\begin{array}{l}\text { 43-year-old } \\
\text { man }\end{array}$ & Lymphoma, kidney transplantation & Solobacterium moorei & $\begin{array}{l}\text { Phenoxymethyl-penicillin } \rightarrow \\
\text { Benzylpenicillin Metronidazole }\end{array}$ & Recovered \\
\hline [12] & Blood culture & $\begin{array}{l}\text { 64-year-old } \\
\text { woman }\end{array}$ & Colon cancer & Solobacterium moorei & Cefuroxime Metronidazole & Recovered \\
\hline [17] & Blood culture & $\begin{array}{l}\text { 61-year-old } \\
\text { man }\end{array}$ & Diabetes mellitus, rectal cancer & $\begin{array}{l}\text { Solobacterium moorei } \\
\text { Streptococcus mitis }\end{array}$ & $\begin{array}{l}\text { Cefuroxime Moxifloxacin } \rightarrow \text { Vancomycin } \\
\text { Meropenem }\end{array}$ & Died \\
\hline [12] & Blood culture & $\begin{array}{l}\text { 66-year-old } \\
\text { woman }\end{array}$ & Non-small cell lung carcinoma & $\begin{array}{l}\text { Solobacterium moorei } \\
\text { Eikenella corrodens }\end{array}$ & $\begin{array}{l}\text { Meropenem } \rightarrow \text { Ciprofloxacin } \\
\text { Metronidazole }\end{array}$ & Recovered \\
\hline [12] & Blood culture & $\begin{array}{l}\text { 33-year-old } \\
\text { woman }\end{array}$ & IVDA Hepatitis B infection & $\begin{array}{l}\text { Solobacterium moorei } \\
\text { Actinomyces meyeri }\end{array}$ & $\begin{array}{l}\text { Cefuroxime } \rightarrow \text { Benzylpenicillin } \\
\text { Metronidazole }\end{array}$ & Recovered \\
\hline [12] & Blood culture & $\begin{array}{l}\text { 77-year-old } \\
\text { man }\end{array}$ & Ischemic heart disease Prostate cancer & $\begin{array}{l}\text { Solobacterium moorei } \\
\text { Porphyromonas } \\
\text { uenonis }\end{array}$ & $\begin{array}{l}\text { Benzylpenicillin } \rightarrow \text { Phenoxy- } \\
\text { methylpenicillin }\end{array}$ & Recovered \\
\hline [18] & Blood culture & $\begin{array}{l}\text { 70-year-old } \\
\text { man }\end{array}$ & HIV- positivity & $\begin{array}{l}\text { Solobacterium moorei } \\
\text { Campylobcater rectus }\end{array}$ & Amoxicillin/clavulanic acid & Recovered \\
\hline [4] & Blood culture & $\begin{array}{l}\text { 37-year-old } \\
\text { man }\end{array}$ & $\begin{array}{l}\text { Femoral vein thrombophlebitis with septic } \\
\text { pulmonary embolism }\end{array}$ & $\begin{array}{l}\text { Solobacterium moorei } \\
\text { Fusobacterium } \\
\text { nucleatum } \\
\text { Bacteroides urealyticus }\end{array}$ & Penicillin Metronidazole & Recovered \\
\hline [5] & Thigh abscess & ND & ND & $\begin{array}{l}\text { Solobacterium moorei } \\
\text { Actinomyces europeus } \\
\text { Enterococcus faecalis } \\
\text { Stenotrophomonas } \\
\text { maltophilia } \\
\text { Comamonas } \\
\text { testosterone } \\
\text { Corynebacterium sp. } \\
\text { Corynebacterium } \\
\text { urealyticum }\end{array}$ & Not reported & Recovered $^{\mathrm{a}}$ \\
\hline [5] & $\begin{array}{l}\text { Abdominal wound } \\
\text { abscess }\end{array}$ & ND & Perforated appendix & $\begin{array}{l}\text { Solobacterium moorei } \\
\text { Peptosterptococcus } \\
\text { micros } \\
\text { Slackia exigua } \\
\text { Bacteroides fragilis } \\
\text { Bilophila wadsworthia } \\
\text { Enterococcus avium } \\
\text { Eikenella corrodens } \\
\text { Escherichia coli }\end{array}$ & Not reported & Recovered $^{\mathrm{a}}$ \\
\hline [5] & Axilla furuncle & ND & ND & $\begin{array}{l}\text { Solobacterium moorei } \\
\text { Stphylococcus aureus } \\
\text { Propionibacterium sp. } \\
\text { Corynebacterium sp. } \\
\text { amycolatum }\end{array}$ & Not reported & Recovered $^{\mathrm{a}}$ \\
\hline [5] & Abdominal wound & ND & ND & $\begin{array}{l}\text { Solobacterium moorei } \\
\text { Prevotella nigrescens } \\
\text { Parvimonas micra } \\
\text { Streptococcus } \\
\text { constellatus } \\
\text { Fusobacterium } \\
\text { nucleatum } \\
\text { Actinomyces turicensis } \\
\text { Dialister pneumosintes } \\
\text { Bacteroides urealyticus } \\
\text { Pseudomonas } \\
\text { aeruginosa } \\
\text { Bacteroides fragilis } \\
\text { Bacteroides ovatus }\end{array}$ & Not reported & Recovered $^{\mathrm{a}}$ \\
\hline [5] & Perirectal abscess & ND & ND & $\begin{array}{l}\text { Solobacterium moorei } \\
\text { Actinomyces turicensis } \\
\text { Streptococcus } \\
\text { anginosus } \\
\text { Bacteroides sp. } \\
\text { Prevotella disiens } \\
\text { Megaspera sp. } \\
\text { Fusobacterium } \\
\text { nucleatum } \\
\text { Porphyromonas sp. }\end{array}$ & Not reported & Recovered $^{\mathrm{a}}$ \\
\hline [5] & Perirectal abscess & ND & Diabetes mellitus & $\begin{array}{l}\text { Solobacterium moorei } \\
\text { Parvimonas micra }\end{array}$ & Not reported & Recovered $^{\mathrm{a}}$ \\
\hline
\end{tabular}


Table 2 (continued)

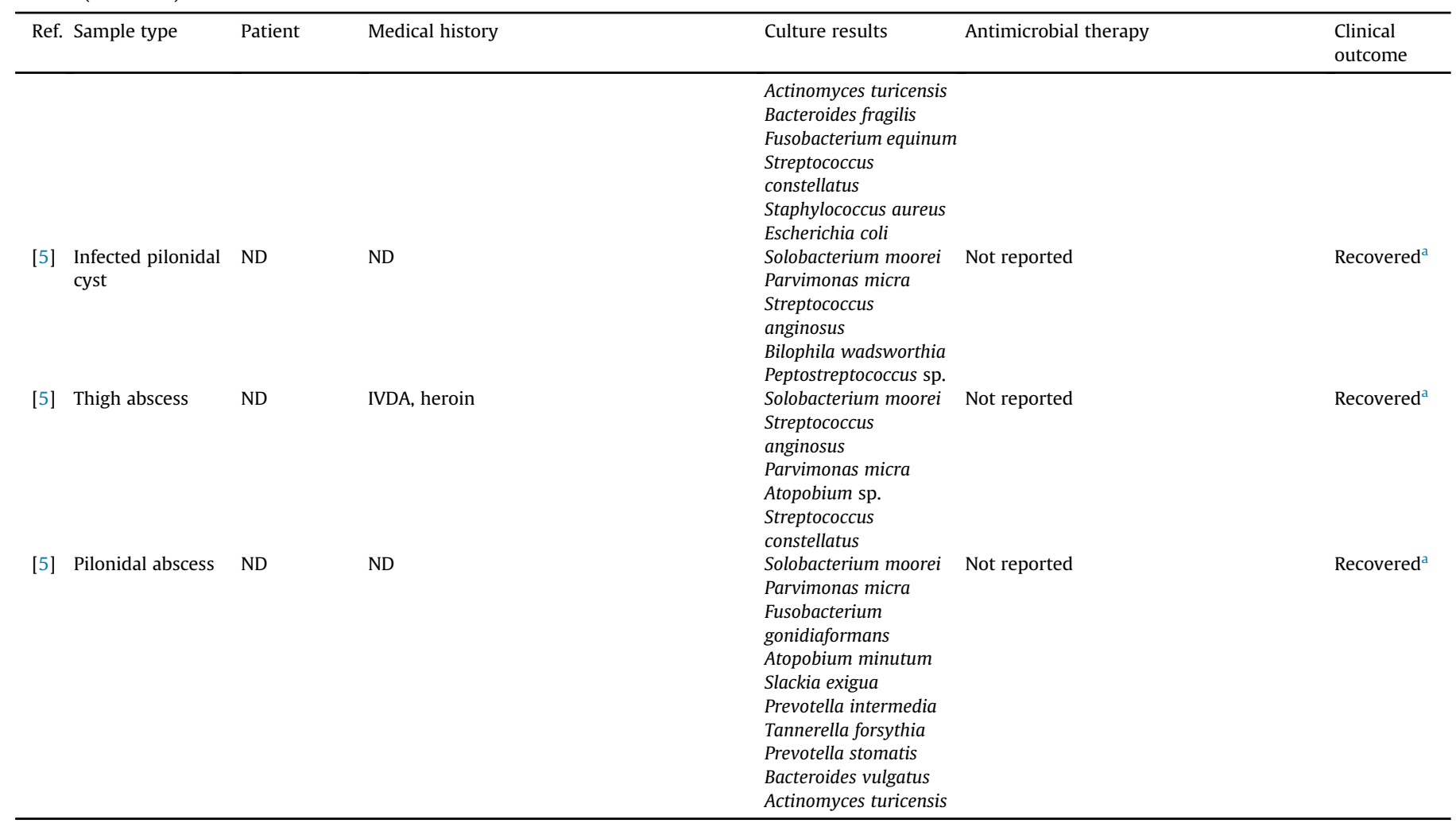

ND: No data IVDA: intravenous drug abuse.

${ }^{a}$ Recovered after surgical intervention and routine antibiotic treatment.

identification of clinical isolates in our laboratory in 2013, a total of 32 S. moorei strains were isolated and identified by the end of 2019. Most of the S. moorei cases (six) were discovered in 2016; these cases are presented in detail in this case report. During subculturing, the clinical isolates of $S$. moorei form small, grey, non-hemolytic colonies with a $0.5-1 \mathrm{~mm}$ diameter on Schaedler blood agar after being incubated for $48 \mathrm{~h}$ in a strict anaerobic environment (Fig. 1). Because of their small colony size, $S$. moorei colonies are often overlooked in mixed culture if the sample is not carefully spread on the original plate. In previous studies that primarily used molecular methods, $S$. moorei was mentioned as a member of a complex microbiome associated with different infections of the oral cavity such as periimplantitis [6], root canal [7], periradicular lesions [8], dentoalveolar abscess [9], apical endodontic abscess [10], and refractory periodontitis [11] together with other anaerobic and aerobic bacteria. Furthermore, it has been suggested that S. moorei, which produces volatile sulfur compounds (e.g., hydrogen sulfide and methyl mercaptan) and organic acids (e.g., amines such as cadaverine, etc.), together with other oral anaerobic bacteria, may play role in the formation of halitosis $[2,16]$.

Altogether, 19 clinical cases have been described in detail since 2006 in which S. moorei was isolated alone or in mixed culture (Table 2). The reported cases of $S$. moorei bacteraemia were mostly associated with cancers: cervix carcinoma with acute proctitis [13], kidney transplantation with lymphoma, lung carcinoma, colon cancer, prostate cancer with pneumonia and ischaemic heart disease [12], and multiple myeloma [3]. Pedersen et al. reported on the isolation of $S$. moorei from the blood culture of a patient who used intravenous drugs and was infected with hepatitis B [12]. Martin et al. reported on $S$. moorei bacteraemia in a case of femoral vein thrombosis with septic pulmonary embolism [4]. In four case reports, S. moorei was isolated from blood culture as the only pathogen, but in some patients, in addition to $S$. moorei, other aerobic or anaerobic bacteria were present in the blood sample (Table 2). Our patient with S. moorei bacteraemia also had several debilitating conditions such as cancer and pyothorax. He died without any antibiotic therapy to treat the sepsis, despite the fact that the blood culture isolate was fully susceptible to all tested antibiotics (Table 1).

Zhen et al. [5] described nine cases of polymicrobial infections that had no clear connection with the oral cavity. These cases were obtained from wound infections, including abdominal abscesses, infected pilonidal cyst and abscess, axilla furuncle, perirectal abscesses, and abdominal wound infections, in which $S$. moorei was isolated with higher or lower colony counts or was detected by $16 \mathrm{~S}$ rRNA gene sequence analysis [5] (Table 2). The antibiotic susceptibility was also determined in a study on six S. moorei isolates. All isolates were fully susceptible to antibiotics usually used for the empirical treatment of mixed infections involving anaerobic bacteria [5]. The five additional polymicrobial cases presented in this report in which $S$. moorei was isolated, together with one to five other different types of bacteria, were also associated with cancers (e.g., colorectal, facial, skin, laryngeal, lung) and immunosuppressive status (e.g., diabetes mellitus, chemotherapy, radiotherapy). In three patients, the infection had a direct connection with the oral cavity (including a middle ear infection, mandibular abscess, and wound infection after total laryngectomy) (Table 1). Except our fifth case, in which $S$. moorei and $A$. randingae were isolated only from the enrichment broth and were not considered real pathogens, the empirically initiated antibiotic therapy covered the mixed flora of the infection (Table 1). In the majority of published bloodstream infections involving $S$. moorei, the patients recovered, but in our 
case, and in a case recently reported by Liu et al. [17], the progression of the infection due to the underlining diseases was rapid with [17] or without antibiotic therapy (our first case), and the patient died.

The introduction of the MALDI-TOF MS method for the identification of slow-growing and difficult-to-identify culturable bacteria or fungi broadened our view about the possible pathogens of mixed infections. Conversely, the more time-consuming PCR-based method to identify culturable or non-culturable members of mixed infections has also been used by several authors [6-9]. The MALDI Biotyper system with various database developments focuses on different, difficult-to-identify species including anaerobic bacteria present in the normal flora or in different infections $[19,20]$. According to our laboratory database, since 2013, we have identified $32 \mathrm{~S}$. moorei strains on the species level with $\log$ (score) values of $\geq 2.000$, including the isolates of the presented cases using the actual database developments of the MALDI Biotyper. Liu W-J. et al. reported that they could not identify their $S$. moorei isolate with commercial biochemical tests or the MALDI-TOF MS method, but they could identify it with 16S rRNA gene sequencing [17]. There is no information on the version of the software applied in that study.

Several publications mention the isolation of $S$. moorei from mixed infections associated with the oral cavity or suggest the possible translocation of it from the gastrointestinal tract. However, the clinical significance of this rarely identified gram-positive anaerobic bacterium remains largely unknown because it is fully susceptible to antibiotics regularly used in mixed infections involving aerobic and anaerobic bacteria. Only one patient died due to sepsis when $S$. moorei was the causative agent with the usage of targeted antibiotic therapy (Table 2). All other bacteraemia patients in whom S. moorei was present in at least one anaerobic blood culture bottle alone or together with some other anaerobic bacteria survived the infection because of appropriate antibiotic therapy. The role of $S$. moorei in other mixed infections with abscess formation in different parts of the body, occasionally involving up to 10 different and mostly anaerobic bacteria, is very difficult to judge [5]. According to the published data and our experience, wound infections involving $S$. moorei resolved after routine surgical management and various anti-anaerobic antibiotic regimens.

S. moorei, which is part of the human microbiota, seems to be a less virulent germ; however, in infectious processes that are connected with several debilitating predisposing factors, the patient may even develop bacteraemia involving $S$. moorei. Our case reports demonstrate the value of the carefully used MALDI-TOF MS method for the identification of anaerobic bacteria including $S$. moorei, the pathogenic role of which should be carefully evaluated in every case.

\section{Ethical approval}

No. 4594

\section{Funding}

This research received no external funding.

\section{Author contributions}

K.P.S. conceived and designed the study, Z.P. wrote case 1, S.K. wrote case 2, R.K. wrote case 3, D.S. wrote case 4, T.V. wrote case 5, B.Sz. wrote case 6 , and K.B. revised the full paper. All authors have read and agreed on the published version of the manuscript.

\section{Declaration of competing interest}

The authors declare no conflicts of interest to disclose, monetary or otherwise.

\section{Acknowledgements}

The authors would like to thank Prof. Dr. Elisabeth Nagy for her valuable proposals and advice during the writing of this manuscript.

\section{References}

[1] A. Kageyama, Y. Benno, Phylogenetic and phenotypic characterization of some Eubacterium-like isolates from human feces: description of Solobacterium moorei gen. nov., sp. nov, Microbiol. Immunol. 44 (2000) 223-227.

[2] V.I. Haraszthy, J.J. Zambon, P.K. Sreenivasan, M.M. Zambon, D. Gerber, R. Rego C. Parker, Identification of oral bacterial species associated with halitosis, JADA 138 (8) (2007) 1113-1120.

[3] G. Detry, D. Pierard, K. Vandoorslaer, G. Wauters, V. Avesani, Y. Glupczynski, Septicemia due to Solobacterium moorei in a patient with multiple myeloma Anaerobe 12 (2006) 160-162.

[4] C.A. Martin, R.S. Wijesurendra, C.D.R. Borland, J.A. Karas, Femoral vein thrombophlebitis and septic pulmonary embolism due to a mixed anaerobic infection including Solobacterium moorei: a case report, J. Med. Case Rep. 1 (40) (2007) 1-3, https://doi.org/10.1186/1752-1947-1-40. Open Access.

[5] G. Zheng, P.H. Summanen, D. Talan, R. Bennion, M.-C. Rowlinson, S.M. Finegold, Phenotypic and molecular characterization of Solobacterium moorei isolates from patients with wound infection, J. Clin. Microbiol. 48 (3) (2010) 873-876.

[6] T. Koyanagi, M. Sakamoto, Y. Takeuchi, M. Ohkuma, Y. Izumi, Analysis of microbiota associated with peri-implantitis using 16S rRNA gene clone library, J. Oral Microbiol. 2 (2010) 5104, https://doi.org/10.3402/jom.v2i0.5104. Open Access.

[7] H.J.A. Rolph, A. Lennon, M.P. Riggio, W.P. Saunders, D. McKenzie, L. Coldero, J. Bragg, Molecular identification of microorganisms from endodontic infections, J. Clin. Microbiol. 39 (2001) 3282-3289.

[8] J.F. Schirrmeister, A.-L. Liebenow, K. Pelz, A. Wittmer, A. Serr, E. Hellwig, A. AlAhmad, New bacterial compositions in root-filled teeth with periradicular lesions, J. Endod. 35 (2009) 169-174.

[9] J. Downes, M.A. Munson, D.A. Spratt, E. Kononen, E. Tarkka, H. JousimiesSomer, W.G. Wade, Characterisation of Eubacterium-like strains isolated from oral infections, J. Med. Microbiol. 50 (2001) 947-951.

[10] N. George, E. Flamiatos, K. Kawasaki, N. Kim, Ch Carriere, B. Phan, R. Joseph, Sh Strauss, R. Kohli, D. Choi, J.C. Baumgartner, Ch Sedgely, T. Maier, C.A. Machida, Oral microbiota species in acute apical endodontic abscesses, J. Oral Microbiol. 8 (2016) 30989, https://doi.org/10.3402/jom.v8.30989. Open Access.

[11] A. Colombo, V. Paula, S. Boches, L. Sean, J. Goodson, R. Kent, A. Haffajee, S. Socransky, Comparison of subgingival microbial profiles of refractory periodontitis, severe periodontitis and periodontal health using the human oral microbe identification microarray, J. Periodontol. 80 (2009) 1421-1432.

[12] R.M. Pedersen, H.M. Holt, U.S. Justesen, Solobacterium moorei bacteremia: identification, antimicrobial susceptibility and clinical characteristics, J. Clin. Microbiol. 49 (7) (2011) 2766-2768.

[13] S.K.P. Lau, J.L.L. Teng, K.-W. Leung, N.K.H. Li, K.H.L. Ng, K.-Y. Chau, T.-L. Que, P.C.Y. Woo, K.-Y. Yuen, Bacteremia caused by Solobacterium moorei in a patient with acute proctitis and carcinoma of the cervix, J. Clin. Microbiol. 44 (8) (2006) 3031-3034.

[14] H. Jousimies-Somer, P. Summanen, D.M. Citron, E.J. Baron, H.M. Wexler, S.M. Finegold, in: Wadsworth-KTL. Anaerobic Bacteriology Manual, sixth ed. Star Publishing Company, Belmont, CA, USA, 2003.

[15] E. Nagy, A. Schuetz, Is there a need for the antibiotic susceptibility testing of anaerobic bacteria? Anaerobe 31 (2015) 2-3.

[16] F. Vancauwenberghe, J. Dadamio, I. Laleman, M. Van Tornout, W. Teughels, W. Coucke, M. Quirynen, The role of Solobacterium moorei in oral malodour J. Breath Res. 7(4)(2013), 046006, https://doi.org/10.1088/1752-7155/7/4/046006,

[17] W.-J. Liu, M. Xiao, J. Yi, T. Kudinha, Y-Ch Xu, First case report of bacteremia caused by Solobacterium moorei in China, and literature review, BMC Infect. Dis. 19 (2019) 730, https://doi.org/10.1186/s12879-019-4359-7.

[18] F.G. Genderini, D. Martiny, F. Ponthieux, M.A. Argudín, M. Gomez Galdon, A. Zaarour, C. Garcia, A. Libois, M. Gérard, N. Dauby, First case of Campylobacter rectus and Solobacterium moorei mixed bacteraemia successfully identified by MALDI TOF-MS, NMNI 31 (2019), 100587.

[19] M. Kostrzewa, E. Nagy, P. Schröttner, A.B. Pranada, How MALDI-TOF mass spectrometry can aid the diagnosis of hard-to-identify pathogenic bacteria the rare and the unknown, Expert Rev. Mol. Diagn. 19 (8) (2019) 667-682.

[20] A.C.M. Veloo, H. Jean-Pierre, U.S. Justesen, T. Morris, E. Urban, I. Wybo, H.N. Shah, A.W. Fridrich, E. Nagy, M. Kostrewa, A multi-center ring trial for the identification of anaerobic bacteria using MALDI-TOF MS, Anaerobe 48 (2017) 94-97. 